\title{
Assessment of riparian zone dynamics and its flood-related implications in Eleyele area of Ibadan, Nigeria
}

\author{
Oluwayemisi S. Olokeogun', Ayansina Ayanlade $2^{2 *}$ and Olusola O. Popoola ${ }^{3}$
}

\begin{abstract}
This study aims at assessing how riparian zones have been altered through various land use activities and the implications of its capacity to mitigate flood. The study focused mainly on examining the land use/land cover changes within the riparian zone over a period of 20 years. The vulnerability of the riparian zone to flood were analyzed using remote sensing datasets. Flood vulnerability models were created based on the elevation and land cover type. A Euclidean distance (700 m) was created using the shuttle radar topographical mapping (SRTM) digital elevation model (DEM) of the lake and its riparian zone. The flood attenuation (150 m buffer) and riparian habitat (500 $\mathrm{m}$ ) zones (areas) within the riparian zone of the lake were then created using the extracted lake boundary. Landsat 7 (for 1999) and 8 (for 2019) covering both zones were classified using the Maximum Likelihood Classification method. The results revealed that the built-up area increased from 2.04 to $4.54 \mathrm{~km}^{2}$ between 1999 and 2019 while water body, grassland, and forest decreased from 0.05 to $0.04 \mathrm{~km}^{2}, 0.37$ to $0.12 \mathrm{~km}^{2}$ and 1.84 to $1.82 \mathrm{~km}^{2}$ over the period of the study. The results further show that about $18.9 \%$ of built-up areas were within the very high vulnerability zone of flood as of the year 2019. The results reveal that the riparian area cover is declining in the study area, despite its ecological services in reducing the effect of floods by slowing down runoff, trapping sediments and enhancing infiltration. The pattern of distribution of the land cover classes at different flood vulnerability levels within zones indicates that the more the alteration of both zones'landscape, the more vulnerable they are to flood. The study concluded that there is a significant level of structural change of the riparian zone which increases its vulnerability level to flooding.
\end{abstract}

Keywords: Riparian zones, Riparian habitat, Flood attenuation, Flood, Vulnerability

\section{Background}

Riparian zones are widely recognized as a bionomical transition zone of material and energy exchange between terrestrial and aquatic ecosystems (Tang et al. 2014). Riparian zones act as an important interface between aquatic and terrestrial ecosystems (Naiman and Decamps 1997), and provide ecological corridors for the migration of wildlife (Hilty and Merenlender 2004; Rodriguez-Iturbe et al. 2009). These zones also provide a range of ecosystem functions and services, e.g., bank stabilization and protection, water

\footnotetext{
*Correspondence: aayanlade@oauife.edu.ng; sinaayanlade@yahoo.co.uk 2 Department of Geography, Obafemi Awolowo University, Ile-Ife, Nigeria Full list of author information is available at the end of the article
}

purification, reservoirs of biodiversity, wetland products, as well as recreation and tourism (Bennett and Simon 2004; Forman 1998; Ghermandi et al. 2009; Holman-Dodds et al. 2003; Hruby 2009; Johnston and Naiman 1990; Sweeney, 1992; Tabacchi et al. 2000; Thoms and Sheldon 2000). The boundaries of Riparian zones are often delineated by vegetation communities along stream banks (Naiman et al. 2010). The delineation and extent of riparian areas vary in part because of their underlying composite and dynamical qualities, but several buffer widths zones for delineating the extent of riparian areas for different purposes (such as water quality protection, stream stabilization, Riparian habitat, flood attenuation, and detrital input) have been suggested and have also received much attention 
from the scientific and regulatory community (Orewole et al. 2015), buffer width of 5-30 m, 10-20 m, $30-500 \mathrm{~m}+, 20-150 \mathrm{~m}$ and $3-10 \mathrm{~m}$ for water quality protection, stream stabilization, Riparian habitat, flood attenuation, and detrital input respectively were recommended and widely used by scholars (Jontos 2004). Flood can be regarded as an overflow or inundation that comes from a river or other body of water and causes or threatens damage. It is a prominent and common natural disaster, irrespective of the state of human development and natural conditions (Agbola et al. 2012). Floods are beneficial to both the river and the riparian zone, but they can be very detrimental to human structures and activities. The frequency, length, and magnitude of floods help to determine both the physical and biological features of the riparian zone (Junk et al. 1989). According to Orewole et al. (2015) several studies have demonstrated that riparian habitats are very significant in water quality, flood and erosion control.

The impacts of floods have increased due to a number of factors which include rising sea level and increased developmental activity on the floodplains. In most cities (including Ibadan) of the world, the problems of floods are rapidly growing (Balogun and Okoduwa 2000). Riparian zones are assumed to mitigate/reduce the effect of floods as they slow water runoff, trap sediment, and enhance infiltration (Letsinger 2003). Despite these proven benefits, the loss and degradation of riparian areas continue, particularly because of urbanization (Burton and Samuelson 2008; Naiman et al. 2010; Poff et al. 2011). Riparian zones have been altered through various land uses. Poff et al. (1997) reported that the remotion of riparian vegetation, drainage of wetlands and exploitation of floodplains leads to larger magnitude floods that cause greater harm to property. Ibadan city, Nigeria has experienced series of flood incidents and has been officially recorded since 1951; the most recent occurred in 2011 and the flood events usually occur in August, a period between the first rainfall peak and the rainfall break. Increased deforestation of the wetlands and riparian forest areas was identified as a vital contributing factor to the incidence of flooding in Ibadan (Agbola et al. 2012). Recently, Eleyele lake has become a focus of human activities, such as urban expansion, agriculture, grazing, erosion, and point, and non-point source pollutions (Agbola et al. 2012; Tope-Ajayi et al. 2016). Man activities have led to the loss of about seventy-eighty percent of the natural riparian area of the lake (Tope-Ajayi et al. 2016). Hence, the need to assess the current status of the zone and its flood vulnerability level.

\section{Methodology}

The study was conducted within the riparian zone of Eleyelye Lake in the Ibadan metropolis (Urban Area), Oyo State, Nigeria (Fig. 1). The lake is situated on latitude $7^{\circ} 25^{\prime} 27.85^{\prime \prime} \mathrm{N}$ and $3^{\circ} 51^{\prime} 20.54^{\prime \prime} \mathrm{E}$. The total area of the lake is approximately $14.4 \mathrm{~km}^{2}$. The elevation of the lake ranges between 166 and $237 \mathrm{~m}$. The lake is characterized by a tropical wet and dry climate, with a lengthy wet season and relatively constant temperatures throughout the course of the year.

The use of Shuttle Radar Topographical Mapping (SRTM) digital elevation model (DEM) data to delineate catchment or stream layers or boundaries was adopted following Orewole et al. (2015). The SRTM data was imported into ArcGIS 10.1 software. The SRTM data was used as input data (Table 1) to create layers such as flow direction, flow accumulation, stream, stream segments, slope grid, catchment grid delineation, catchment polygon, and drainage line and adjoint catchment. These layers were then overlaid on a Google Earth Image in order to identify Eleyele Lake. The lake boundary was then extracted.

Furthermore, $150 \mathrm{~m}$ and $500 \mathrm{~m}$ buffer were created (using the lake boundary as input data) in order to define the flood attenuation (FA) and the riparian habitat (RH) boundaries (layers) respectively. FA is the riparian buffer zone that promotes floodplain storage due to backwater effects; they intercept overland flow and increase travel time, resulting in reduced flood peaks, while RH represents the extent of a riparian zone (Jontos 2004) (Fig. 2).

The satellite imagery (Landsat 7 and 8) covering the study area were subjected to pre-processing operations which include; geometrical rectification and image registration, radiometric and atmospheric correction. Optimum Index Factor (OIF) was used to select the optimum combination of three bands out of all possible 3-band combinations in the satellite image using ILWIS. Band 742 (of Landsat 7) and Band 432 (of Landsat 8) combination were finally selected (based on the result of the OIF) and then stacked, subset and processed into colour composites. The RH and FA layers were extracted from the two colour composites using ArcGIS 10.1 and supervised classification were then carried out on the extracted layers using the Maximum Likelihood Classifier of Erdas 2014 in order to produce land Cover maps for both $\mathrm{RH}$ and FA zones. Four (4) land cover classes were defined (Table 2). The training set was collected using existing maps, higher resolution spectral images (Google Earth) and Visual interpretation as a guide. Validation was also performed for the classified images using the Validation set (which was obtained from Fieldwork, existing maps, high-resolution spectral images and Visual interpretation of the same image). Land cover changes were examined 


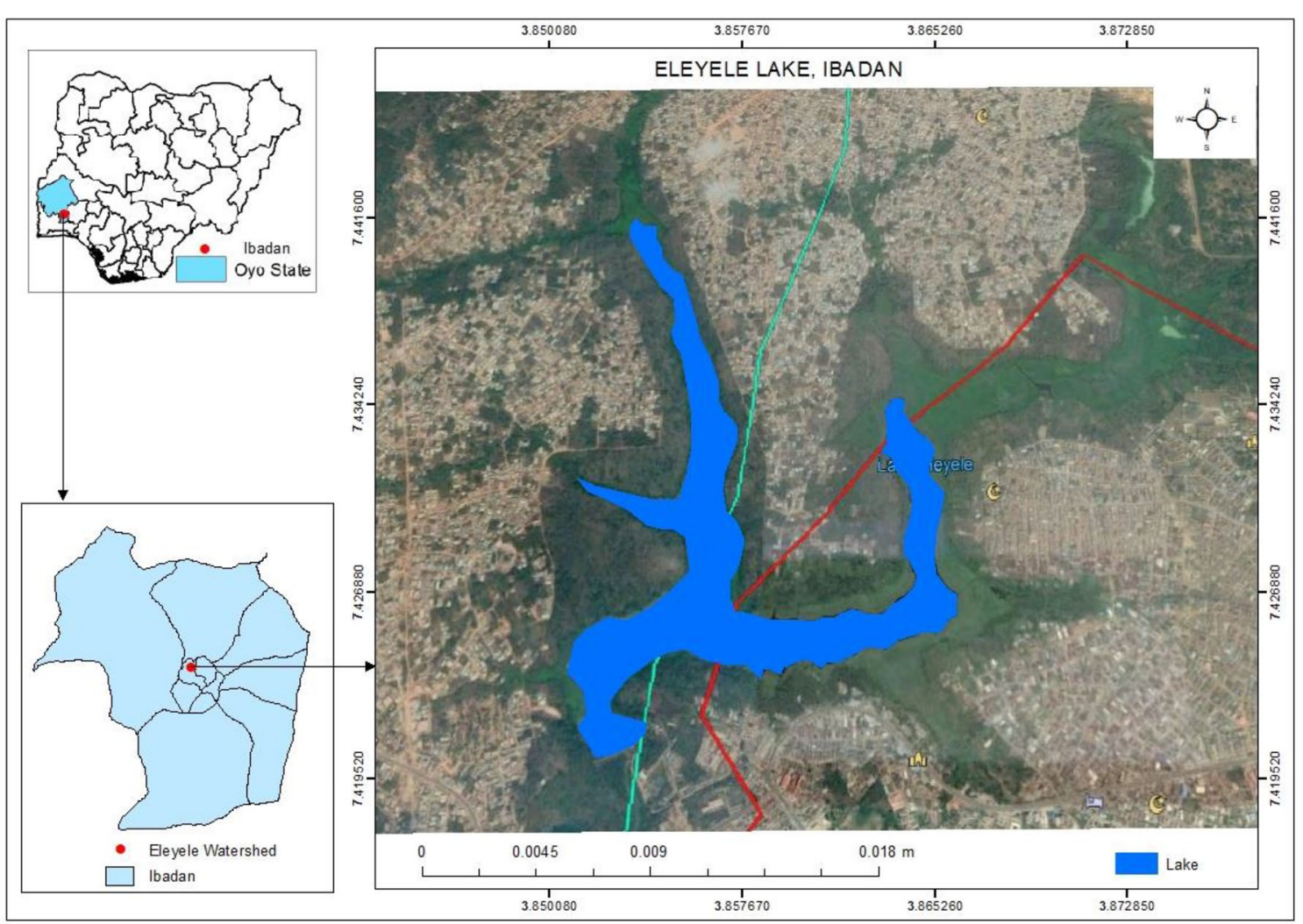

Fig. 1 Location of the study area

\section{Table 1 Information about the dataset}

\begin{tabular}{|c|c|c|c|}
\hline Dataset & Resolution & Date & Source \\
\hline Landsat 8 images & $\begin{array}{l}30 \times 30 \mathrm{~m}(\text { band } 1-7,9), 15 \times 15 \mathrm{~m}(\text { band } 8) \\
100 \times 100 \mathrm{~m}(\text { band } 10-11)\end{array}$ & $01-01-2019$ & United State Geological Survey (USGS) EarthExplorer website \\
\hline Landsat 7 images & $30 \times 30 \mathrm{~m}$ (band 1-7). $15 \times 15 \mathrm{~m}$ (band 8) & 13-12-1999 & United State Geological Survey (USGS) EarthExplorer website \\
\hline $\begin{array}{l}\text { Shuttle radar topo- } \\
\text { graphic mission } \\
\text { (SRTM) }\end{array}$ & $30 \mathrm{~m}$ & & United State Geological Survey (USGS) EarthExplorer website \\
\hline Google earth image & & & Google earth website \\
\hline
\end{tabular}

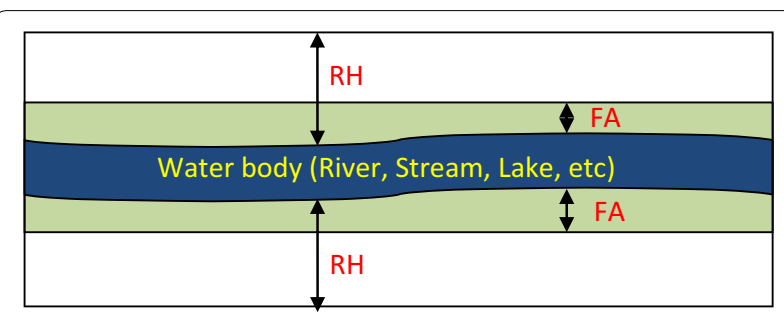

Fig. 2 Description of flood attenuation and riparian habitat zones
Table 2 Land cover classification scheme and their general description Source: Fu et al. (2017)

\begin{tabular}{lll}
\hline S/N & Classes & Description \\
\hline 1 & Waterbody & Rivers, reservoirs fishery and lakes \\
2 & Build-up & Industrial and commercial, residential, transportation \\
3 & Grassland & High-, mid- and low-cover grassland \\
4 & Forest & $\begin{array}{l}\text { Arboreal forest, sparse woodland, and shrub wood- } \\
\text { land }\end{array}$ \\
& &
\end{tabular}


on the produced land cover maps for RH and FA zones over a period of 20 years (1999 and 2019). Elevation models (Elevation and Slope) of both zones were also generated using ArcGIS 10.1 in order to provide a representative sample of the complex and diverse landforms found in both areas.

\section{$\mathrm{S} / \mathrm{N}$ classes description}

1. Waterbody rivers, reservoirs fishery and lakes.

2. Build-up industrial and commercial, residential, transportation.

3. Grassland high-, mid- and low-cover grassland.

4. Forest arboreal forest, sparse woodland, and shrub woodland.

The flood vulnerability models were created based on the elevation and land cover type using ArcGIS 10.1. The vulnerability models were categorized into low, moderate, high and very high level. Each of the vulnerability factor (the elevation and land cover type) were normalized from 1 (low) to 4 (very high) and summed to produce an overall vulnerability score (1-4) following Copeland et al. (2010). A Euclidean distance $(700 \mathrm{~m})$ was created using the SRTM DEM of the lake and its riparian zone. The lake layer was then extracted from the Euclidean distance DEM. Land cover map (1999 and 2019) of the RH zone and the Euclidean distance DEM was reclassified (based on Jenks Natural Break Classification) into four (4) classes each. The vulnerability model (for 1999 and 2019) was then created with the reclassified layers using the raster calculator tool. The percentage of land cover classes at different flood vulnerability levels within $\mathrm{RH}$ and FA zone were then identified using the Zonal Histogram tool. The number of buildings that are susceptible at different vulnerable levels within both zones was also identified through an overlay analysis following Orewole et al. (2015) with building shapefile of Eleyele and the vulnerability levels as input data.

\section{Result and discussion}

The changes within the $\mathrm{RH}$ and FA zones of the study area were presented in Figs. 3, 4 and 5. A supervised (full Gaussian) maximum likelihood classification was implemented for the images and the final classification provided an overview of the major land cover classes/
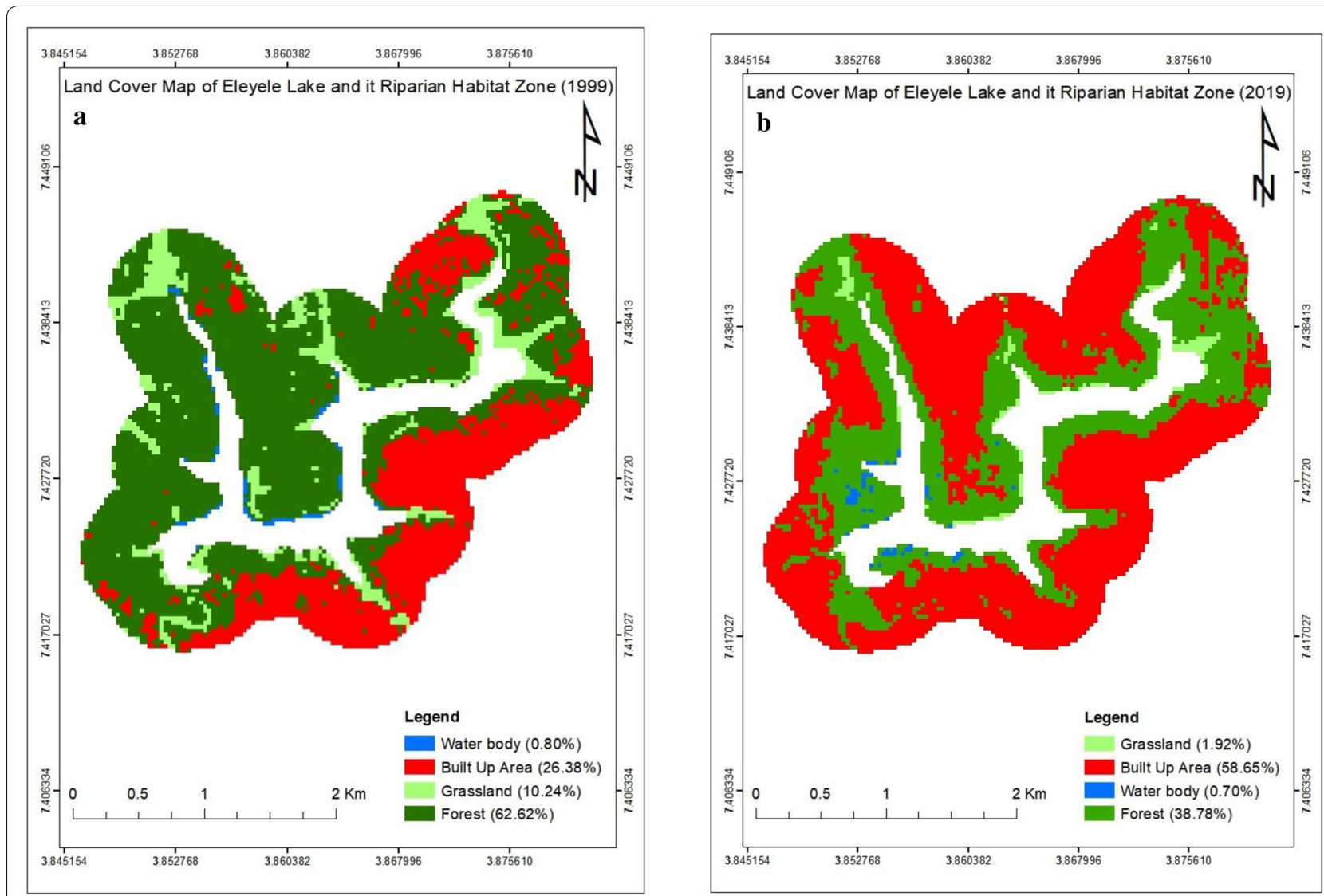

Fig. 3 Land cover map of the riparian habitat zone of Eleyele lake between 1999 (a) and 2019 (b) 

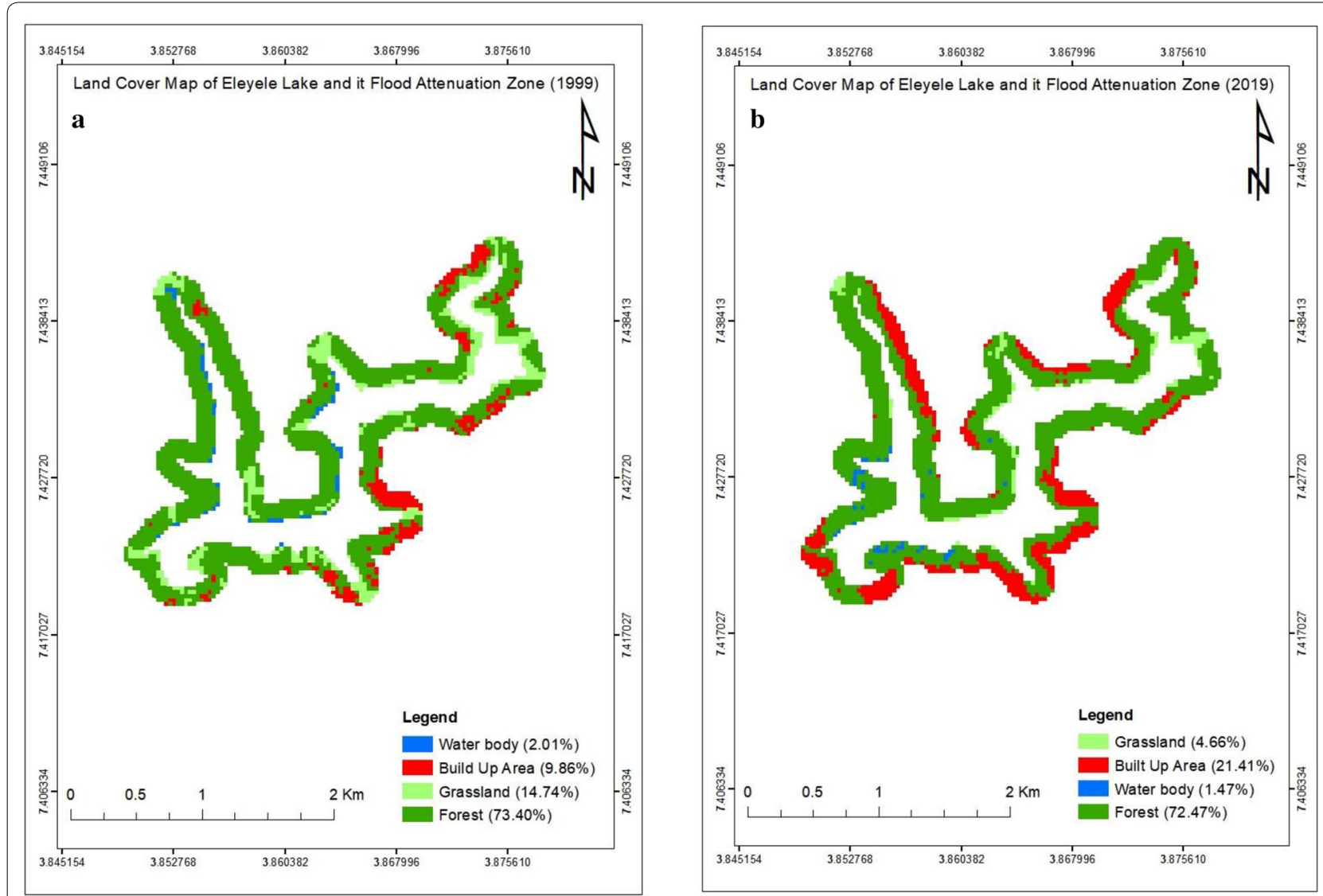

Fig. 4 Land cover map of the flood attenuation zone of Eleyele lake between 1999 (a) and 2019 (b)

features of RH and FA zones for the years 1999 and 2019. The defined land cover classes (Water Bodies, Built-Up Area, Grassland and Forest) were identified. Figures 3 and 4 illustrate the land cover maps (1999 and 2019) of $\mathrm{RH}$ and FA areas, while Fig. 5 illustrates the changes (in land area/size) within the areas between 1999 and 2019.

The forest land cover class of the RH zone had the highest percentage cover (62.62\%) in the year 1999, followed by Built-Up Area class (26.38\%) and Grassland class (10.24\%), while Water body class had the least with $0.80 \%$ (Fig. 3a). In 2019, the Built-up area had the highest percentage cover (58.65\%) followed by Forest class (38.78\%), Grassland (1.92\%), while the water body had the least with $0.70 \%$ (Fig. 3b). Also, the Forest land cover class of FA zone had the highest percentage cover $(73.40 \%)$, followed by Grassland (14.74\%), Built-up area (9.86\%), while Water body class had the least with $2.01 \%$ (Fig. 4a). In 2019 , the Forest land cover class had the highest percentage cover (72.47\%), followed by Grassland (4.66\%), Builtup area (21.41\%), while Water body class had the least with $1.47 \%$ (Fig. 4b).

Furthermore, the water body, grassland and forest class of $\mathrm{RH}$ zone decreased from $0.06-0.05 \mathrm{~km}^{2}$,
$0.79-0.15 \mathrm{~km}^{2}$ and $4.85-3 \mathrm{~km}^{2}$ respectively, while the built-up area increased from $2.04-4.54 \mathrm{~km}^{2}$ between 1999 and 2019 (Fig. 5a). Also within the FA zone, waterbody, grassland, and forest class also decreased from $0.05-0.04 \mathrm{~km}^{2}, 0.37-0.12 \mathrm{~km}^{2}$ and $1.84-1.82 \mathrm{Km}^{2}$, while the built-up area increased from 0.25 to $0.54 \mathrm{~km}^{2}$ between 1999 and 2019 (Fig. 5b).

\section{Topographic factors}

The elevation and slope of the RH zone and FA zone were presented in Figs. 6 and 7. The minimum and maximum elevations of the RH zone are $166 \mathrm{~m}$ and $237 \mathrm{~m}$ above the mean sea level respectively (Fig. 6a), while the minimum and maximum elevations of the FA zone are $169 \mathrm{~m}$ and $237 \mathrm{~m}$ above the mean sea level respectively (Fig. 6b). The slope of the RH zone and FA zone ranges from 0 to 83 percent slope (Fig. 7a, b). Both zones have a steeper slope along the northwest, northeast, and southeast part, and a gentle slope along the southwest part.

\section{Flood vulnerability analysis}

The vulnerability levels in the RH zone and FA zone to flood between 1999 and 2019 were presented in Figs. 8a, 

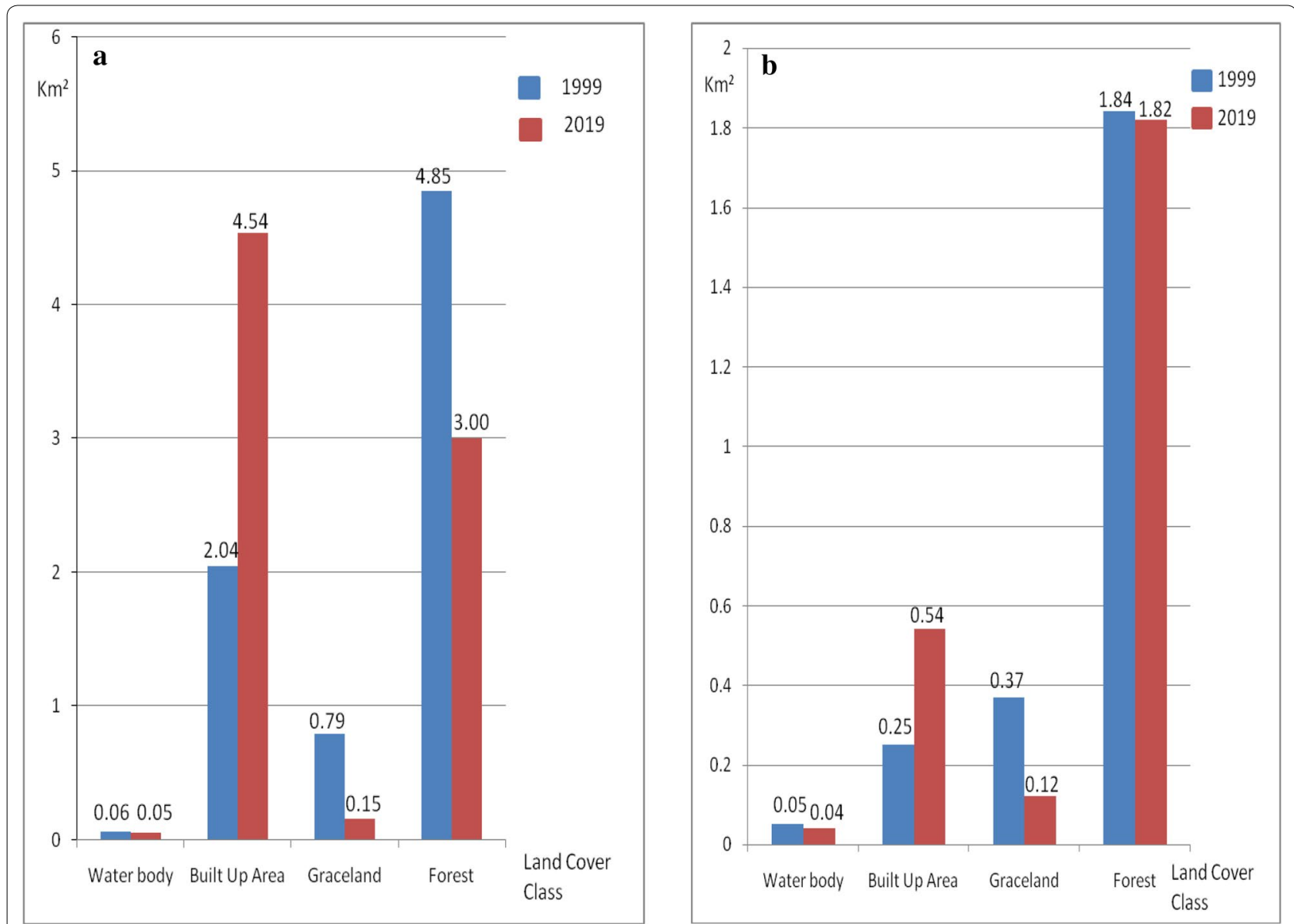

Fig. 5 Land area/size changes within the riparian habitat zone (a) and flood attenuation zone (b) of Eleyele Lake

b, 9 and Tables 3, 4. The vulnerability of the zones to flood was categorized into low, moderate, high and very high based on Jenks Natural Breaks classification method.

Table 3 above showed the percentage of each land cover class at different flood vulnerability levels in the RH zone between 1999 and 2019. The total percentage (100\%) of water body class was within low vulnerability level in 1999 , while $2 \%, 36 \%$, and $62 \%$ were within moderate, high and very high vulnerability levels respectively in 2019. Also, $38.89 \%$ and $61.11 \%$ of built-up area class were within low and moderate vulnerability levels respectively in 1999 , while $21.14 \%, 19.33 \%, 40.67 \%$, and $18.86 \%$ were within low, moderate, high and very high vulnerability level respectively in 2019.

Furthermore, $35.12 \%$ and $64.88 \%$ of grassland class were within moderate and high vulnerability levels respectively in 1999 , while $6.33 \%$ and $93.67 \%$ were within a high and very high vulnerability level respectively in 2019 . Then $16.48 \%, 34.32 \%$ and $49.2 \%$ of the forest class were within moderate, high and very high vulnerability level respectively in 1999 , while $0.69 \%$,
$6.02 \%, 21.45 \%$, and $71.84 \%$ were within low, moderate, high and very high vulnerability level respectively in 2019.

Table 4 above showed the percentage of each land cover class at different flood vulnerability levels in the FA zone between 1999 and 2019. The total percentage (100\%) of water body class was within low vulnerability level in 1999 , while $18.92 \%$ and $81.08 \%$ were within high and very high vulnerability levels respectively in 2019. Also, the total percentage (100\%) of built-up area class was within moderate vulnerability level respectively in 1999, while $1.65 \%, 27.22 \%$, and $71.13 \%$ were within moderate, high and very high vulnerability levels respectively in 2019 .

Furthermore, $2.78 \%$ and $97.22 \%$ of grassland class were within moderate and high vulnerability levels respectively in 1999 , while the total percentage (100\%) of the class was within a very high vulnerability level in 2019. In addition, $3.2 \%$ and $96.8 \%$ of the forest class were within high and very high vulnerability levels respectively in 1999 , while $1.97 \%, 14.39 \%$, and $83.64 \%$ were within moderate, high and very high vulnerability levels respectively in 2019 . 

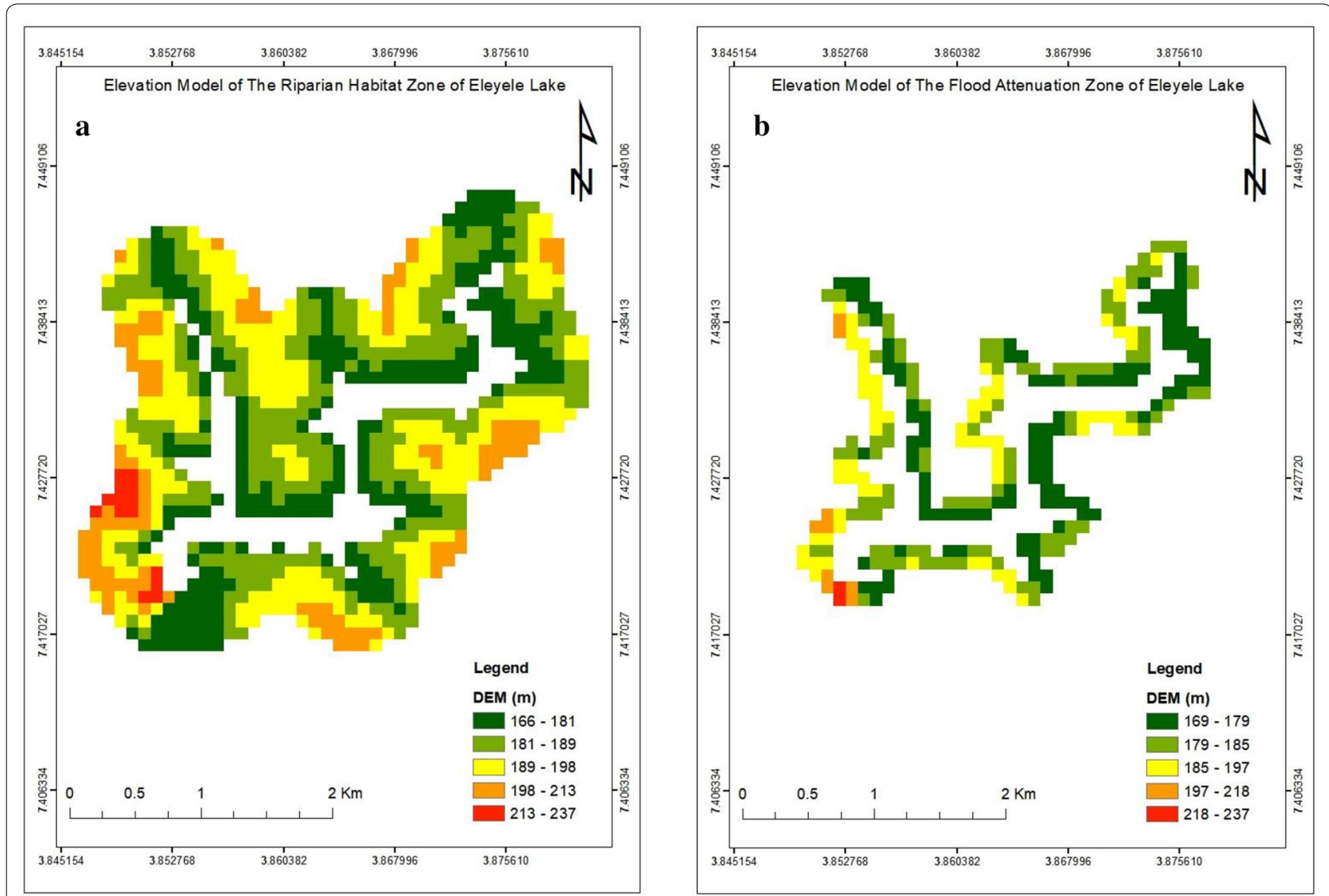

Fig. 6 Digital elevation model of the riparian habitat zone (a) and flood attenuation zone (b)

Figure 9 above reveals the number of building at different vulnerability levels presently within RH and FA zones. A total number of 3114 and 502 buildings were identified within $\mathrm{RH}$ and FA zones respectively. At the $\mathrm{RH}$ zone, the High vulnerability level has the highest number of buildings (1120), followed by Low and Moderate vulnerability level (with 957 and 553 respectively), while the Very high vulnerability level has the least with 484 buildings. Furthermore, at the FA zone, the Very high vulnerability level has the highest number of buildings (332), followed by High and Moderate vulnerability levels (with 152 and 18 respectively), while the low vulnerability level has the least with zero (0) building.

\section{Discussion}

The results reported above show the past and current status of the RH zone and FA zone of Eleyele Lake and its flood-related implications over a period of 20 years. Such information is essential for effective and efficient planning, monitoring and management of riparian zones in order to mitigate flood occurrence and also reduce its effects. Four major land cover classes (Waterbody, Built-Up Area, Graceland, and Forest) were identified.
Akingbogun et al. (2012) reported five land cover classes (water body, build-up area, farmland, vegetation and forest plantation) between 1972 and 2000. Tope-Ajayi et al. (2016) also reported four land cover classes (water body, build-up area, agro-forestry, and wetland forest) between 1984 and 2000.

The water body, Grassland and Forest classes of both zones decreased while the built-up area increased (Fig. 5a, b). This suggests that the structure of both zones have significantly changed over the past 20 years; while the structure of both zones (in 1999) showed signs of human-induced fragmentation, the structure was significantly more fragmented in 2019. This finding is in line with Oyinloye et al. (2004) and corroborates Tope-Ajayi et al. (2016). Also, the presence of a built-up class within both zones is contrary to the general belief that the riparian zone should be a zone free of human settlement. According to Apan et al. (2002), Riparian zones comprises of patches or corridors of unique vegetation types, wetlands, and other land uses such as agricultural crops and pasture.

Furthermore, the rate of decrease in both the grassland and forest is a major concern as this will definitely 

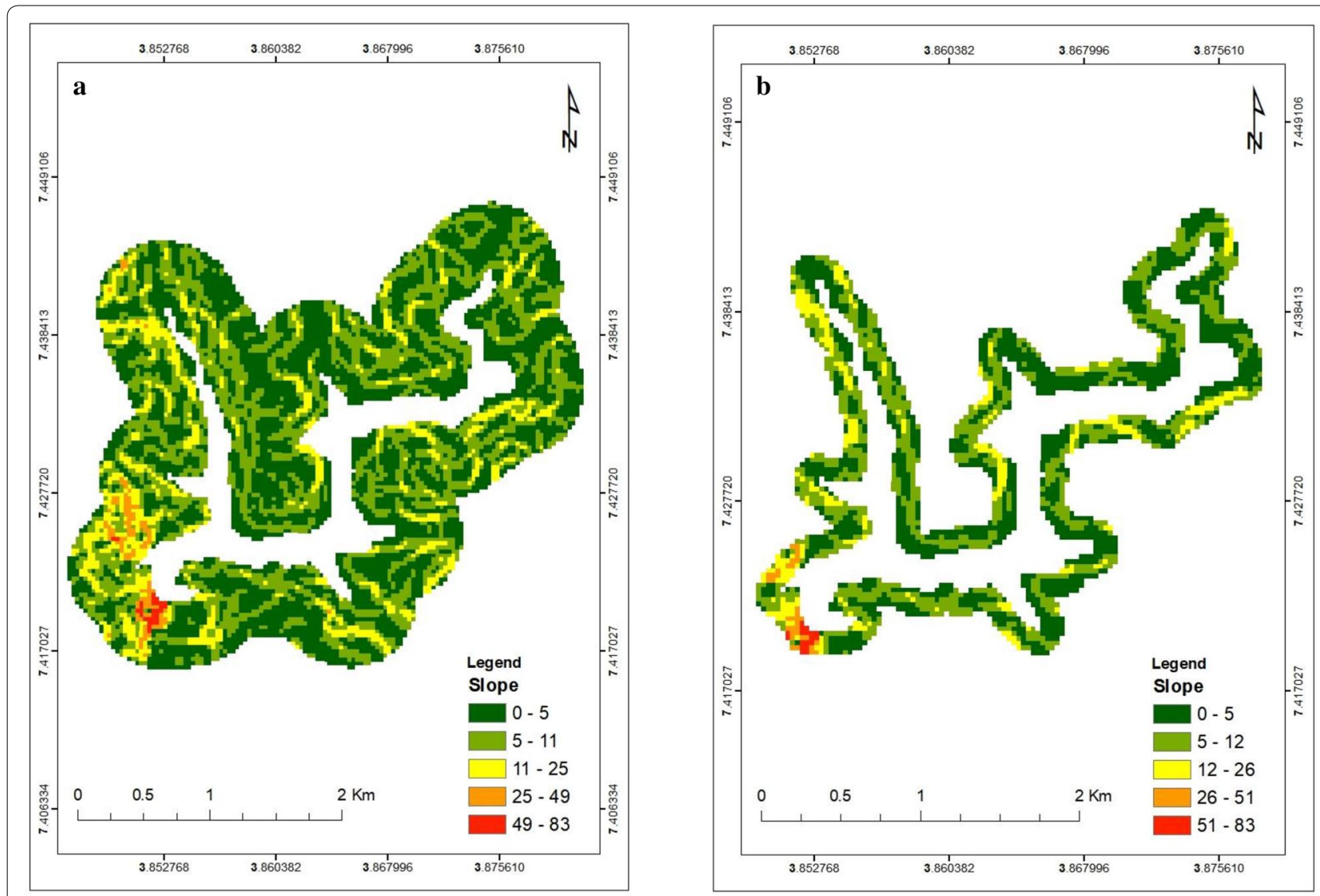

Fig. 7 Slope map of the riparian habitat zone (a) and flood attenuation zone (b)
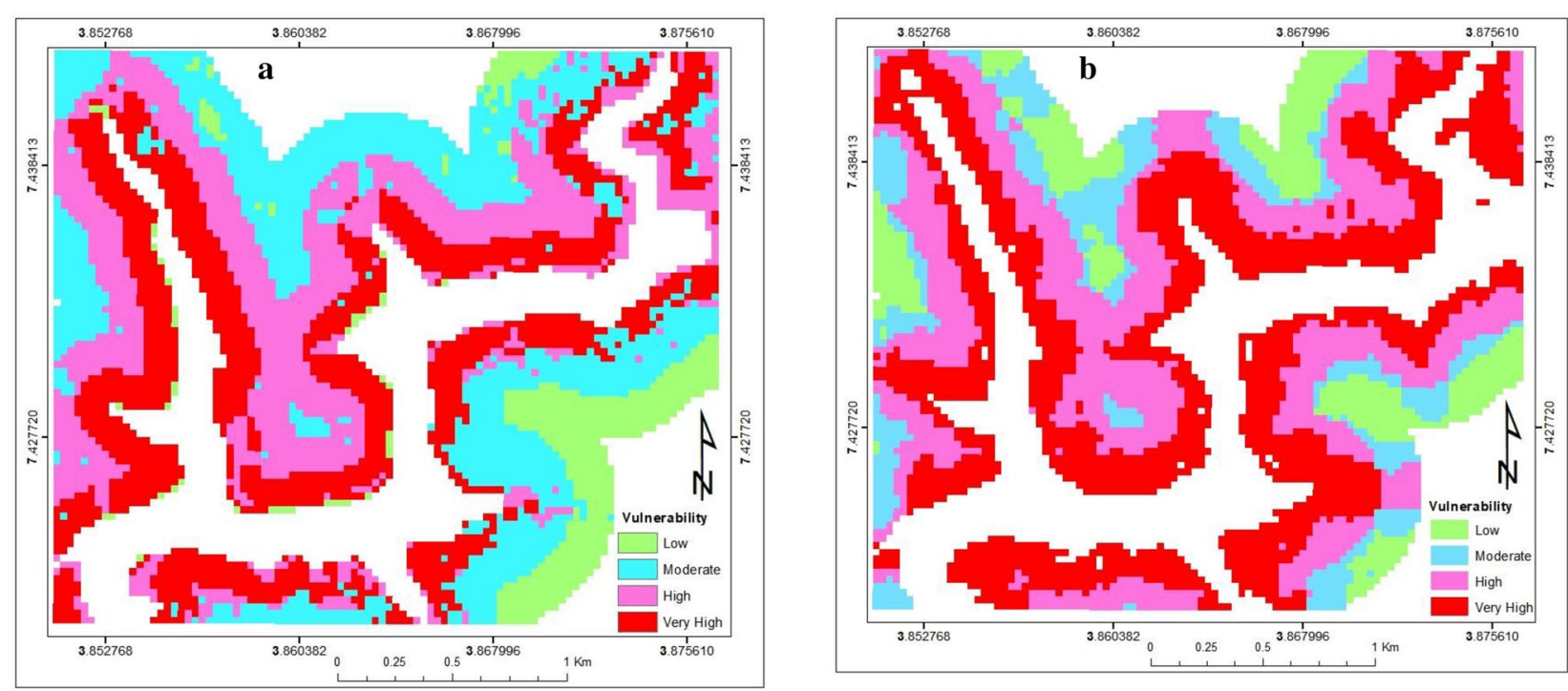

Fig. 8 Flood vulnerability of Eleyele riparian zone 1999 (a) and 2019 (b) 


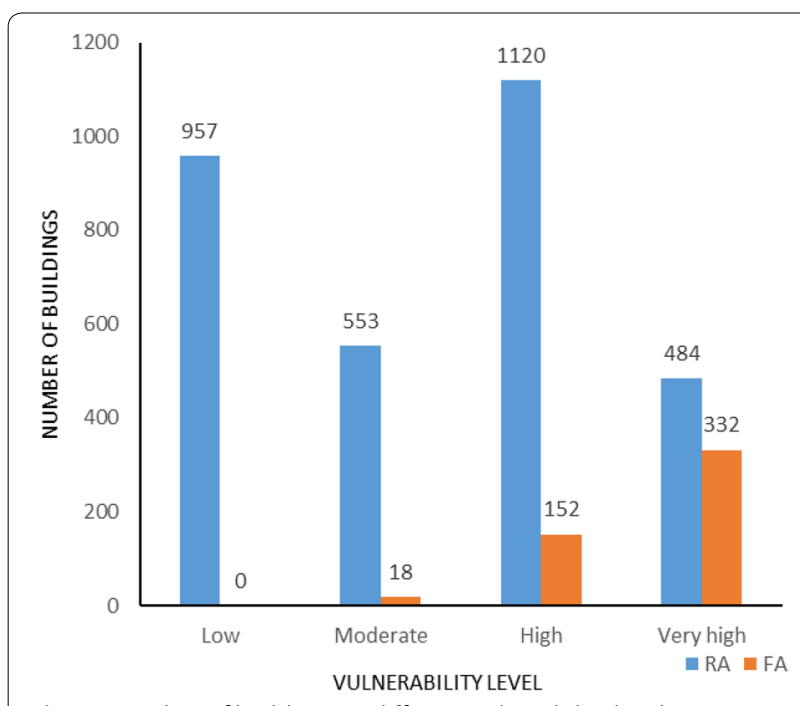

Fig. 9 Number of buildings at different vulnerability levels

have an adverse impact on their capacity to perform their functions. According to Apan et al. (2002), undisturbed forests within riparian zones play a vital role in regulating the upstream-downstream movement of water, matter, and energy. Also, riparian vegetation (grassland and forest) has an important role in relation to channel stability, soil erosion, water quality, fish habitat and water quality (Gregory et al. 1991; Kuusemets and Mander 1999; Vought et al. 1995). High, relatively open forest canopies increase light intensity at water's surface but dense, low, closed canopies reduce the light intensity at water's surface (Savita et al. 2019). The level of shading offered to streams and lakes by riparian vegetation is a function of their structure and composition (Gregory et al. 1991). In addition, the rate of increase of built-up area within both zones is of great concern especially at the FA zone as this zone is meant to reduce flood peaks. According to Tope-Ajayi et al. (2016), the increase can be ascribed to the growing demand for land and the need for urban development.

The elevation of RA and FA zones ranges from $166 \mathrm{~m}$ to $237 \mathrm{~m}$ above the mean sea level (Fig. 6a, b). According to Copeland et al. (2010), wetlands and its riparian zone in lower elevation areas are likely to have higher vulnerability scores. Both zones also have a steeper slope along the northwest, northeast, and southeast part, and a gentle slope along the southwest part (Fig. 7a, b). According to Hawes and Smith (2005), the steeper the land within a riparian zone, the wider it needs to be to have time to slow the flow of water and absorb the pollutants and sediments within it. Broadmeadow and Nisbet (2004) reported that many researchers suggest that steep slopes serve little value as a riparian buffer. Lü et al. (2010) found that faster runoff is often produced by steeply sloped fields.

The pattern of distribution of the land covers classes at different flood vulnerability levels within both zones between 1999 and 2019 (Tables 3, 4) suggest that the more the alteration of both zones' landscape, the more vulnerable they are to flood. This finding is in line with Copeland et al. (2010). The vulnerability level of the builtup area class within the flood attenuation zone (Table 4) is alarming. Ideally, the existence of such class within this zone is not an ideal situation, because its presence

Table 3 Percentage of land cover classes at different flood vulnerability level in the riparian habitat (RH) zone

\begin{tabular}{|c|c|c|c|c|c|c|c|c|}
\hline \multirow[t]{2}{*}{ Vulnerability level } & \multicolumn{2}{|c|}{ Water body (\%) } & \multicolumn{2}{|c|}{ Built-up area (\%) } & \multicolumn{2}{|c|}{ Grassland (\%) } & \multicolumn{2}{|c|}{ Forest (\%) } \\
\hline & 1999 & 2019 & 1999 & 2019 & 1999 & 2019 & 1999 & 2019 \\
\hline Low & 100 & - & 38.89 & 21.14 & - & - & - & 0.69 \\
\hline Moderate & - & 2 & 61.11 & 19.33 & 35.12 & - & 16.48 & 6.02 \\
\hline High & - & 36 & 0 & 40.67 & 64.88 & 6.33 & 34.32 & 21.45 \\
\hline Very high & - & 62 & 0 & 18.86 & - & 93.67 & 49.2 & 71.84 \\
\hline
\end{tabular}

Table 4 Percentage of land cover classes at different flood vulnerability level in the flood attenuation (FA) zone

\begin{tabular}{|c|c|c|c|c|c|c|c|c|}
\hline \multirow[t]{2}{*}{ Vulnerability level } & \multicolumn{2}{|c|}{ Water body (\%) } & \multicolumn{2}{|c|}{ Built-up area (\%) } & \multicolumn{2}{|c|}{ Grassland (\%) } & \multicolumn{2}{|c|}{ Forest (\%) } \\
\hline & 1999 & 2019 & 1999 & 2019 & 1999 & 2019 & 1999 & 2019 \\
\hline Low & 100 & - & - & - & - & - & - & - \\
\hline Moderate & - & - & 100 & 1.65 & 2.78 & - & - & 1.97 \\
\hline High & - & 18.92 & - & 27.22 & 97.22 & - & 3.2 & 14.39 \\
\hline Very high & - & 81.08 & - & 71.13 & - & 100 & 96.8 & 83.64 \\
\hline
\end{tabular}


reduces the capacity of the zone to perform its functions effectively and efficiently. According to Pinay (1986), FA zone is an area of natural riparian woods, it is not a zone used for habitation or agriculture. In addition, Copeland et al. (2010) also reported residential development along or within a riparian zone is a man-made obstruction and a complex situation that can lead to flooding which requires urgent attention.

The identified number of buildings at different vulnerability levels within both zones (Fig. 9) indicates the buildings that are susceptible to flood incidence. The number of buildings at Very high and High vulnerability level within both zones corroborate the findings of Orewole et al. (2015) and also suggest the need for predisaster assessment within the study area. According to Olugunorisa (2009), infrastructure within disaster (such as flood, earthquake, and drought) prone areas requires urgent actions such as pre-disaster assessment. The predisaster assessment comprises planning, mitigation and preparedness phases (Olugunorisa 2009; Orewole et al. 2015).

\section{Conclusion}

This research focused on the assessment of riparian zone dynamics and its flood-related implications in the Eleyele area of Ibadan, Nigeria. The findings reveal the existence of land cover changes within RH and FA zones of the study area over a period of 20 years (1999 and 2019), in which the water body, grassland, and forest land cover class decreased while built-up area increased drastically. These changes are significantly human-induced. There is a significant level of structural change of the riparian zone which increases its vulnerability level to flooding.

\section{Abbreviations \\ SRTM: Shuttle radar topographical mapping; DEM: Digital elevation model; FA: Flood attenuation; RH: Riparian habitat; OIF: Optimum index factor; RS: Remote sensing; GIS: Geographic information system.}

\section{Acknowledgements}

The authors thank the Africa Regional Center for Space Science and Technology Education-English, Obafemi Awolowo University, Ile-Ife, Nigeria, for hosting this research and providing initial remote sensing training.

\section{Authors' contributions}

OOS developed the conception and every aspect of this study; AA played the leading role in the supervision of the research project, through which the paper was developed, POO co-supervised the research project and help in proofreading the manuscript. All authors read and approved the final manuscript.

\section{Funding}

The author(s) received no financial support for the research, authorship, and/ or publication of this article.

\section{Availability of data and materials}

The data will be made available only on request.
Ethics approval and consent to participate Not applicable.

\section{Consent for publication}

Not applicable.

\section{Competing interests}

The authors declared that there is no conflict of interest in this paper.

\section{Author details}

${ }^{1}$ Department of Forestry Technology, Federal College of Forestry, Ibadan, Nigeria. ${ }^{2}$ Department of Geography, Obafemi Awolowo University, lle-Ife, Nigeria. ${ }^{3}$ Department of Urban and Regional Planning, Federal University of Technology, Akure, Nigeria.

Received: 16 October 2019 Accepted: 28 February 2020

Published online: 10 March 2020

\section{References}

Agbola BS, Ajayi O, Taiwo OJ, Wahab BW (2012) The August 2011 flood in Ibadan, Nigeria: anthropogenic causes and consequences. Int J Disaster Risk Sci 3:207-217

Akingbogun AA, Kosoko OS, Aborisade DK (2012) Remote sensing and GIS application for forest reserve degradation prediction and monitoring, in first FIG young surveyors conference, knowing to create the future, Rome p 4-5

Apan AA, Raine SR, Paterson MS (2002) Mapping and analysis of changes in the riparian landscape structure of the Lockyer Valley catchment, Queensland, Australia. Landsc Urban Plan 59:43-57

Balogun F, Okoduwa A (2000) Application of GIS in flood risk mapping: a case study of Benin City. Nige J Cartogr GIS 1:37-46

Bennett SJ, Simon A (2004) Riparian vegetation and fluvial geomorphology. American Geophysical Union, Washington

Broadmeadow S, Nisbet TR (2004) The effects of riparian forest management on the freshwater environment: a literature review of best management practice

Burton ML, Samuelson L (2008) Influence of urbanization on riparian forest diversity and structure in the Georgia Piedmont, US. Plant Ecol 195:99-115

Copeland HE, Tessman SA, Girvetz EH, Roberts L, Enquist C, Orabona A, Patla S, Kiesecker J (2010) A geospatial assessment on the distribution, condition, and vulnerability of Wyoming's wetlands. Ecol Indic 10:869-879

Forman RTT (1998) Road ecology: a solution for the giant embracing us. Landsc Ecol 13:3-5

Fu B, Li Y, Wang Y, Campbell A, Zhang B, Yin S, Zhu H, Xing Z, Jin X (2017) Evaluation of riparian condition of Songhua River by integration of remote sensing and field measurements. Sci Rep 7:2565

Ghermandi A, Vandenberghe V, Benedetti L, Bauwens W, Vanrolleghem PA (2009) Model-based assessment of shading effect by riparian vegetation on river water quality. Ecol Eng 35:92-104

Gregory SV, Swanson FJ, McKee WA, Cummins KW (1991) An ecosystem perspective of riparian zones. Bioscience 41:540-551

Hawes E, Smith M (2005) Riparian buffer zones: functions and recommended widths. Eightmile River Wild Scen Study Comm 15:2005

Hilty JA, Merenlender AM (2004) Use of riparian corridors and vineyards by mammalian predators in northern California. Conserv Biol 18:126-135

Holman-Dodds JK, Bradley AA, Potter KW (2003) Evaluation of hydrologic benefits of infiltration based urban storm water management 1. JAWRA J Am Water Resour Assoc 39:205-215

Hruby T (2009) Developing rapid methods for analyzing upland riparian functions and values. Environ Manage 43:1219-1243

Johnston CA, Naiman RJ (1990) Browse selection by beaver: effects on riparian forest composition. Can J For Res 20:1036-1043

Jontos R (2004) Vegetative buffers for water quality protection: an introduction and guidance document. Connect Assoc Wetl Sci White Pap Veg Buffers Draft version 1:22

Junk WJ, Bayley PB, Sparks RE (1989) The flood pulse concept in river-floodplain systems. Can Spec Publ Fish Aquat Sci 106:110-127 
Kuusemets V, Mander Ü (1999) Ecotechnological measures to control nutrient losses from catchments. Water Sci Technol 40:195-202

Letsinger SL (2003) Development of amethod toassess riparian vegetated buffer zones using GIS and remote sensing in youngs creek watershed, Johnson County, Indiana, In: 2003 Seattle annual meeting

Lü XT, Yin JX, Tang JW (2010) Structure, tree species diversity and composition of tropical seasonal rainforests in Xishuangbanna, south-west China. J Trop For Sci 260-270

Naiman RJ, Decamps H (1997) The ecology of interfaces: riparian zones. Annu Rev Ecol Syst 28:621-658

Naiman RJ, Decamps H, McClain ME (2010) Riparia: ecology, conservation, and management of streamside communities. Elsevier, Amsterdam

Olugunorisa T (2009) Strategies for mitigation of flood risk in the Niger Delta, Nigeria. J Appl Sci Environ Manag 13(2):17-22

Orewole MO, Alaigba DB, Oviasu OU (2015) Riparian corridors encroachment and flood risk assessment in Ile-Ife: a GIS perspective. Open Trans Geosci 2:19-20

Oyinloye RO, Agbo BF, Aliyu ZO (2004) Land use/land cover mapping in Osun State using NigeriaSat-1 Data

Pinay G (1986) Relations sol-nappe dans les bois riverains de la Garonne: étude de dénitrification

Poff NL, Allan JD, Bain MB, Karr JR, Prestegaard KL, Richter BD, Sparks RE, Stromberg JC (1997) The natural flow regime. Bioscience 47:769-784

Poff B, Koestner KA, Neary DG, Henderson V (2011) Threats to riparian ecosystems in Western North America: an analysis of existing literature 1. JAWRA J Am Water Resour Assoc 47:1241-1254

Rodriguez-Iturbe I, Muneepeerakul R, Bertuzzo E, Levin SA, Rinaldo A (2009) River networks as ecological corridors: a complex systems perspective for integrating hydrologic, geomorphologic, and ecologic dynamics. Water Resour Res 45

Savita PK, Sharma LK, Kumar M (2019) Forestry interventions for ganga rejuvenation: a geospatial analysis for prioritizing sites. Indian For 144:1127-1135

Sweeney B (1992) Streamside forests and the physical, chemical, and trophic characteristics of piedmont streams in eastern North America. Water Sci Technol 26:2653-2673

Tabacchi E, Lambs L, Guilloy H, Planty-Tabacchi A, Muller E, Decamps H (2000) Impacts of riparian vegetation on hydrological processes. Hydrol Process 14:2959-2976

Tang Q, Bao Y, He X, Zhou H, Cao Z, Gao P, Zhong R, Hu Y, Zhang X (2014) Sedimentation and associated trace metal enrichment in the riparian zone of the three gorges reservoir. China Sci Total Environ 479:258-266

Thoms MC, Sheldon F (2000) Lowland rivers: an Australian introduction. Regul River 16:375-383

Tope-Ajayi OO, Adedeji OH, Adeofun CO, Awokola SO (2016) Land use change assessment, prediction using remote sensing, and gis aided markov chain modelling at eleyele wetland area, Nigeria. J Settl Spat Plan 7:51

Vought LB-M, Pinay G, Fuglsang A, Ruffinoni C (1995) Structure and function of buffer strips from a water quality perspective in agricultural landscapes. Landsc Urban Plan 31:323-331

\section{Publisher's Note}

Springer Nature remains neutral with regard to jurisdictional claims in published maps and institutional affiliations.

\section{Submit your manuscript to a SpringerOpen ${ }^{\circ}$ journal and benefit from:}

- Convenient online submission

- Rigorous peer review

- Open access: articles freely available online

- High visibility within the field

- Retaining the copyright to your article

Submit your next manuscript at $\boldsymbol{\nabla}$ springeropen.com 